\title{
EXTL3 wt Allele
}

National Cancer Institute

\section{Source}

National Cancer Institute. EXT L3 wt Allele. NCI Thesaurus. Code C50964.

Human EXT L3 wild-type allele is located within 8p21 and is approximately $52 \mathrm{~kb}$ in length.

This allele, which encodes exostosin-like 3 protein, is involved in both chain initiation and elongation during heparin/heparin sulfate biosynthesis. 